\title{
Effect of Dietary Chromium, Vitamin E and Selenium Supplementation on Growth Performance and Cost Economics of Holstein Friesian Calves Under Heat Stress
}

\author{
Razia Sultana Janampet ${ }^{1 *}$, Sarat Chandra Amaravadhi ${ }^{1}$, Ramana Damarla Bala Venkata ${ }^{5}$, Raghunandan \\ Thirunahari ${ }^{2}$, Gnana Prakash Manthani ${ }^{3}$ and Venkateswarlu Malisetty ${ }^{4}$ \\ ${ }^{1}$ Department of Livestock Production Management, College of Veterinary Science, Rajendranagar, Telangana, INDIA \\ ${ }^{2}$ Comptroller, P.V. Narsimha Rao Telangana Veterinary University, Rajendranagar, Telangana, INDIA \\ ${ }^{3}$ Director of Research, P.V. Narsimha Rao Telangana Veterinary University, Rajendranagar, Telangana, INDIA \\ ${ }^{4}$ Department of Animal Nutrition, College of Veterinary Science Rajendranagar, Hyderabad, Telangana, INDIA \\ ${ }^{5}$ CRIDA, Hyderabad, Santoshnagar, Telangana, INDIA \\ *Corresponding author: R S Janampet; E-mail: drrazia0204@gmail.com
}

Received: 4 Feb., 2021

Revised: 16 May, 2021

Accepted: 19 May, 2021

\begin{abstract}
A study was conducted in Holstein Friesian calves with an average body weight $172.79 \pm 4.39 \mathrm{~kg}$ and aged 7-8 months for a period of 90 days during the months of peak summer (April 15-July 15). Calves were distributed randomly into four dietary treatment groups of six animals each considering their body weights. The treatment groups were T0 (control), T1, T2 and T3. The calves of control group were fed total mixed ration (TMR). Other treatment groups were fed with TMR supplemented with chromium propionate@0.5mg/kg DM (T1); vitamin E @ 500 IU/animal/day and selenium @ 0.3 mg/kg DM (T2) and chromium propionte @ $0.5 \mathrm{mg} / \mathrm{kg}$ DM, vitamin E @ 500 IU/animal/day and selenium @ $0.3 \mathrm{mg} / \mathrm{kg}$ DM (T3). The mean THI values were $75.10 \pm 0.42$ in the morning and $80.01 \pm 0.64$ in the afternoon indicating that the animals were under mild to moderate heat stress. High THI was found in the month of May with a THI value $83.48 \pm 1.41$ in the afternoon. Dry matter intake $(\mathrm{kg} / \mathrm{d})$, DMI per $100 \mathrm{~kg}$ BW and per $\mathrm{kg} \mathrm{BW}{ }^{0.75}$ were comparable among the calves fed different experimental rations. DMI per kg weight gain was significantly $(\mathrm{P}<0.05)$ lesser in $\mathrm{T} 3$ calves. Weight gain and the average daily gain were significantly $(\mathrm{P}<0.05)$ higher with supplemented rations compared to control ration. Supplemented rations were found to be economic. However chromium fed rations proved to be more profitable.
\end{abstract}

\section{HIGHLIGHTS}

(0 Heat stress influences dry matter intake and growth performance of calves.

(0 Chromium is a promising agent for combating the adverse effects of heat stress in animals.

o Vitamin E and selenium act synergistically and reduce oxidative stress.

Keywords: Calves, Chromium, Economics, Growth performance, Heat stress

Homeotherms have optimal temperature zones or thermoneutral zones for production within which animal's body temperature remains relatively constant. Exposure of animal to the atmospheric temperature above the thermoneutral zone may alter the physiological functions of animal and animal may be called as heat stressed (Patel et al., 2016). Heat stress is shown to affect negatively feed intake, health status, immune status (Salio et al.,
2015; Lacerda and Loureiro, 2015), growth performance in tropical and subtropical regions of the world (Habeeb,

How to cite this article: Janampet, R.S., Amaravadhi, S.C., Venkata R.D.B., Thirunahari, R., Manthani, G.P. and Malisetty, V. (2021). Effect of dietary chromium, vitamin $\mathrm{E}$ and selenium supplementation on growth performance and cost economics of holstein Friesian calves under heat stress. J. Anim. Res., 11(3): 387-392.

Source of Support: None; Conflict of Interest: None 
2020) resulting in a significant financial burden to the dairy industry (Biffani et al., 2016; Polsky and von Keyserlingk, 2017) Although calves and heifers are comparatively heat resistant due to less production of metabolic heat and more heat dissipation efficiency, they still suffer from heat stress to some degree. Dry matter intake and growth performance of calves and heifers are reduced during heat stress because of redistributing energy to heat regulation through a series of physiological and metabolic responses, such as elevated blood insulin and protein catabolism (Wang et al., 2020).

Modifications in the behavioral, psychological and biochemical thermoregulatory mechanisms are not sufficient to cope up with the heat stress. Hence implementing approaches like shelter management, nutritional strategies as well as improved health services can have significant impact in ameliorating the heat stress effect on livestock sector. Chromium is an essential mineral for human and animals and plays an important role in glucose metabolism (Lashkari et al., 2018). Furthermore, chromium has been considered a promising agent for combating the adverse effects of heat stress in animals due to its strong antioxidant activities by preventing lipid peroxidation (Bin-Jumah et al., 2020). Heat stress induces oxidative stress in animals (Mirzad et al., 2018). Oxidative stress is defined as the presence of reactive species in excess of the available antioxidant capacity of animal cells (Akbarian et al., 2016). Vitamin E and Selenium are documented antioxidants (Domosławska et al., 2018). The purpose of the present study is to investigate the effects of dietary Chromium, vitamin E and selenium supplementation on growth performance and cost economics in summer exposed calves.

\section{MATERIALS AND METHODS}

Present study was carried out according to the norms of Institutional Animal ethics committee of the university.

\section{Site of study}

The present study was conducted at Kapila Agro Farm, a commercial dairy farm situated at Timmareddypally village of Kondapak mandal in Siddipet district, Telangana State, located at $17^{\circ} 58^{\prime} 25.7^{\prime \prime}$ North and $78^{\circ}$ $51 ' 56.5^{\prime}$ "East, at an altitude of 547 meters above the sea level. Analysis of blood and feed sample was carried out at ICAR-CRIDA (ICAR-Central Research Institute for Dryland Agriculture), Santoshnagar, Hyderabad.

\section{Temperature humidity index (THI)}

Ambient air temperature and humidity were measured for calculation of THI. Dry bulb and wet bulb temperatures were recorded twice a day at 10.00 AM and 3.00 PM using dry and wet bulb thermometers placed about $1.5 \mathrm{~m}$ above the ground level. The degree of heat stress was determined according to mean THI values measured. THI was estimated for the entire study period as per Bianca (1962).

$$
T H I=\left(0.35 \times T_{d b}+0.65 \times T_{w b}\right) \times 1.8+32
$$

Where, $T_{d b}$ : Dry bulb temperature and $T_{w b}$ : Wet bulb temperature $\left({ }^{0} \mathrm{C}\right)$

\section{Animals and diet}

The trial was conducted for a period of 90 days during peak summer season (April 15 to July 15) in the year 2017 on twenty four H.F calves with an average body weight $172.96 \pm 4.39 \mathrm{~kg}$ and aged $7-8$ months. They were randomly distributed into four groups to contain six animals in each group. The group averages of body weights in all the four groups were as uniform as possible. Calves either received a basal diet devoid of any supplementation (T0) or were supplemented with chromium propionate @ $0.5 \mathrm{mg} / \mathrm{kg}$ DM (T1); vitamin E@ 500 IU/animal/day and selenium @ $0.3 \mathrm{mg} / \mathrm{kg} \mathrm{DM}$ (T2) and chromium propionate @ 0.5 mg/kg DM, vitamin E@ 500 IU/animal/day and selenium ( $0.3 \mathrm{mg} / \mathrm{kg} \mathrm{DM}$ (T3). All the calves were stall fed, reared under standard management conditions and housed in tie stalls with fans.

All the groups were fed total mixed ration (TMR) diet twice daily. The TMR contained chopped paddy straw, maize green (sweet corn with cobs and grains in milk stage) and concentrate mixture with roughage: concentrate ratio of 70:30. Fifty per cent of the daily allocation was provided in the morning feeding at 8.00 am and fifty per cent in the evening at $4.00 \mathrm{pm}$ during the trial period. The basal diet was formulated to contain all the necessary nutrients to meet the nutrient requirements recommended by ICAR (2013). Ingredient composition of TMR for calves consisting of maize, wheat bran and soya bean 
meal, limestone powder, salt, mineral mixture and sodium bicarbonate is given in Table 1. They had free access to fresh and clean water all the time. The proximate analysis and fiber fractions of feeds was performed as per the procedures described by AOAC (2005) and Van Soest (1991) methods respectively.

Feed offered and feed refusal was monitored thrice weekly for each group of calves and feed intake was calculated. At the beginning of the experiment, all the calves were weighed using an electronic digital balance for three consecutive days in the morning before feeding and watering. Then calves were weighed individually at fortnight intervals before feeding and watering to observe the body weight changes for an experimental period of 90 days.

\section{Cost economics}

The total cost of experimental feeds per quintal was calculated on the basis of processing cost (electricity and labour charges) and prevailing market rates of the feed ingredients including paddy straw and maize green.

\section{Chemical and Statistical analysis}

Samples of TMR were collected, dried overnight in a hot air oven at $100 \pm 5^{\circ} \mathrm{C}$ and then ground in laboratory Willey mill and preserved in airtight containers for further chemical analysis. The proximate analysis of feeds was performed as per the procedures described by AOAC
(2005). Statistical analysis of the data was carried out according to the procedures suggested by Snedecor and Cochran (1994). Least-square Analysis of variance was used to test the significance of various treatments and the difference between treatments means was tested for significance by Duncan's new multiple range and F Test (Duncan, 1955).

\section{RESULTS AND DISCUSSION}

\section{Environmental conditions and micro environment}

Temperature humidity index (THI) at the start of experiment ( $1^{\text {st }}$ week of April) averaged $75.83 \pm 0.22$ in the morning (10.00 AM) and $80.44 \pm 0.85$ in the afternoon (3.00PM) and the THI decreased with the decrease in environmental temperature in July to $72.25 \pm 0.31$ and $76.69 \pm 0.48$ in the morning and afternoon, respectively. The mean THI during 90 days of experimental period was $75.10 \pm 0.42$ in the morning and $80.01 \pm 0.64$ in the afternoon indicating the animals were under heat stress. Highest THI was found in the month of May with a THI value $83.48 \pm 1.41$ in the afternoon.

\section{Chemical composition of feed}

The per cent of crude protein in the TMR fed to the growing calves was 13.90 percent on a dry matter basis (Table 1). In the present study, the CP values for the maize fodder and paddy straw were 8.68 and 3.4 percent, respectively.

Table 1: Chemical composition of experimental feeds (\% DM) fed to Holstein Friesian calves

\begin{tabular}{|c|c|c|c|c|c|}
\hline Sl. No. & Nutrient & TMR & $\begin{array}{l}\text { Concentrate } \\
\text { Mixture }\end{array}$ & Paddy straw & Maize \\
\hline \multicolumn{6}{|c|}{ Proximate composition } \\
\hline 1 & Dry matter & 54.50 & 93.61 & 95.35 & 23.96 \\
\hline 2 & Organic matter & 85.98 & 89.86 & 85.54 & 92.67 \\
\hline 3 & Crude protein & 13.90 & 20.84 & 3.40 & 8.68 \\
\hline 4 & Ether extract & 2.02 & 3.22 & 1.24 & 1.91 \\
\hline 5 & Crude fibre & 14.02 & 6.16 & 31.68 & 25.12 \\
\hline 6 & Total ash & 10.96 & 10.14 & 14.46 & 7.33 \\
\hline 7 & Nitrogen free extract & 59.10 & 59.40 & 49.22 & 56.96 \\
\hline \multicolumn{6}{|c|}{ Van Soest fibre fractions } \\
\hline 8 & Neutral detergent fiber & 59.85 & 56.37 & 83.56 & 75.99 \\
\hline 9 & Acid detergent fiber & 22.05 & 14.94 & 51.09 & 37.70 \\
\hline
\end{tabular}




\section{Dry matter intake and weight gain}

The results indicated that the DMI, DMI per $100 \mathrm{~kg} \mathrm{BW}$ and DMI per $\mathrm{kg} \mathrm{BW} \mathrm{BW}^{0.75}$ were not significantly different among four groups of calves fed experimental rations but relatively higher DMI was found in the supplemented groups compared to control group. DMI increased with the increase in the body weight of the calves in all the groups (Table 2). The variation in environmental variables such as relative humidity and temperature seems to affect the feed intake of the control group calves. DMI per $\mathrm{kg}$ weight gain was significantly $(p<0.05)$ higher in control group calves compared to the T3 group and the values were relatively higher than $\mathrm{T} 1$ and $\mathrm{T} 2$ indicating a positive effect of supplementation on growth performance. A number of reports confirm decreased sensitivity to stress in chromium supplemented animals through a reduced concentration of cortisol in blood (Abdelnour et al., 2019; Kumar et al., 2015). Mousavi et al. (2019) and Kargar et al. (2018b) reported that supplementation of chromium to dairy calves under heat stress resulted in increase in DMI. Similarly Chauhan et al. (2016) also reported increased average daily feed intake with vitamin $\mathrm{E}$ and selenium supplementation. Vitamin $\mathrm{E}$ and $\mathrm{Se}$ are considered crucial nutrients possessing various biological functions as antioxidants to prevent cellular injury triggered by reactive oxygen species (Mahmood et al., 2020). Vitamin $\mathrm{E}$ is a lipid-soluble molecule that acts within the lipid membrane to avoid the formation of hydroperoxides while Se is an important component of glutathione peroxidase to detoxify the hydrogen peroxide before damaging cellular molecules (Soliman et al., 2012). Both reduce oxidative stress and thereby increase performance (Kumbhar et al., 2018).
Statistical analysis of data revealed significantly $(p<0.05)$ higher weight gain in calves supplemented with antioxidants compared to the control group. T3 group calves supplemented with chromium, vitamin E and selenium showed significantly $(\mathrm{P}<0.05)$ higher weight gain followed by $\mathrm{T} 1$ group supplemented with chromium alone and then $\mathrm{T} 2$ group supplemented with vitamin $\mathrm{E}$ and selenium. The calves fed T1, T2 and T3 ration also showed significantly $(p<0.05)$ higher ADG compared to the control group. These results are in agreement with Soltan et al. (2012) and Abdoun et al. (2015) who reported a significant increase in weight gain in calves supplemented with chromium. Chromium supplementation improves growth rate and body weight by enhancing the absorption and digestion of nutrients (Ghorbani et al., 2012; Kargar et al., 2018a). Contrary to our results Mousavi et al. (2019) did not find significant difference in weight gain in calves supplemented with chromium. Sushma et al. (2015) and Chauhan et al. (2016) also reported an improvement in body weight in kids and lambs, respectively with vitamin $\mathrm{E}$ and selenium supplementation. Improvement in body weight in T1, T2 and T3 groups could be attributed to the mitigation of oxidative stress due to supplementation and thereby increase in DMI and feed efficiency.

\section{Cost economics}

In the present study supplemented diets were found to be more economical than the control group. Cost of feed per $\mathrm{kg}$ weight gain was approximately $6.81,4.36$ and 8.57 percent lower for $\mathrm{T} 1, \mathrm{~T} 2$ and $\mathrm{T} 3$ ration than the $\mathrm{T} 0$ ration which might be attributed to better feed efficiency as a result of low oxidative stress. Similar findings were

Table 2: Dry matter intake and weight gain of experimental animals

\begin{tabular}{|c|c|c|c|c|}
\hline Parameter & T0 & T1 & T2 & T3 \\
\hline DMI (kg/d) & $6.67 \pm 0.20$ & $6.76 \pm 0.23$ & $6.74 \pm 0.22$ & $6.82 \pm 0.23$ \\
\hline DMI (kg/100 kg BW) & $3.26 \pm 0.01$ & $3.28 \pm 0.02$ & $3.27 \pm 0.01$ & $3.28 \pm 0.02$ \\
\hline DMI (g/kg BW $\left.{ }^{0.75}\right)$ & $1.76 \pm 0.04$ & $1.78 \pm 0.05$ & $1.77 \pm 0.04$ & $1.79 \pm 0.05$ \\
\hline DMI per kg weight gain & $8.70 \pm 0.25^{b}$ & $8.13 \pm .18^{a b}$ & $8.31 \pm 0.17^{a b}$ & $8.02 \pm 0.13^{\mathrm{a}}$ \\
\hline Initial body weight & $172.67 \pm 8.76$ & $172.33 \pm 9.58$ & $173.17 \pm 9.73$ & $173.00 \pm 9.55$ \\
\hline Final body weight & $242.83 \pm 8.84$ & $247.83 \pm 10.38$ & $247.00 \pm 10.65$ & $250.50 \pm 9.08$ \\
\hline Weight gain & $70.17 \pm 1.01^{\mathrm{a}}$ & $75.50 \pm 1.23^{\mathrm{bc}}$ & $73.83 \pm 1.47^{b}$ & $77.50 \pm 0.67^{\mathrm{c}}$ \\
\hline $\mathrm{ADG}$ & $0.78 \pm 0.01^{\mathrm{a}}$ & $0.84 \pm 0.01^{\mathrm{b}}$ & $0.82 \pm 0.02^{\mathrm{b}}$ & $0.86 \pm 0.01^{\mathrm{b}}$ \\
\hline
\end{tabular}

*a, b,c means with different superscripts row wise differ significantly $(\mathrm{P}<0.05)$. 
Table 3: Cost economics for different experimental rations fed to calves

\begin{tabular}{lllll}
\hline Parameter & T0 & T1 & T2 & T3 \\
\hline Feed Intake (kg/d) & 12.39 & 12.55 & 12.52 & 12.62 \\
Total feed cost (₹) & 50.44 & 51.08 & 51.42 & 51.88 \\
Labour cost (₹/d) & 125.00 & 125.00 & 125.00 & 125.00 \\
Miscellaneous (₹) & 3.21 & 3.21 & 3.21 & 3.21 \\
Total Expenditure (₹) & 178.65 & 179.29 & 179.63 & 180.09 \\
ADG (kg) & 0.78 & 0.84 & 0.82 & 0.86 \\
Cost per kg weight gain & 229.04 & 213.45 & 219.06 & 209.40 \\
\hline
\end{tabular}

reported by Abdoun et al. (2015) who conducted a trial on male camel calves divided into three groups with a control group fed on total mixed ration and the other two treatment groups provided basal diet supplemented with $0.5 \mathrm{mg} \mathrm{Cr} / \mathrm{kg} \mathrm{DM}$ and $1.0 \mathrm{mg} \mathrm{Cr} / \mathrm{kg} \mathrm{DM}$ and concluded that chromium supplementation reduced feeding cost of producing a unit of weight by $11 \%$. Vinu et al. (2012) also found that the feed cost per kilogram body weight gain for the calves supplemented organic selenium was more economical than the control group.

\section{ACKNOWLEDGEMENTS}

The authors are grateful to the University Grants Commission for financial support (MANF 2017-18 F1-17.1/2017-18/MANF-2017-18-TEL-84155) of this experiment and also to ICAR-CRIDA \& NICRA project for providing facilities for nutritional analysis of feeds and feed ingredients.

\section{CONCLUSION}

Results of the present study indicated that supplementation of chromium propionate alone or in combination with non enzymatic antioxidants improved the growth performance and proved to fetch more profits. Hence supplementation of chromium is suggested for profitable growth rate.

\section{REFERENCES}

Abdelnour, S.A., Abd El-Hack, M.E., Khafaga, A.F., Arif, M., Taha, A.E. and Noreldin, A.E. 2019. Stress biomarkers and proteomics alteration to thermal stress in ruminants. $J$. Therm. Biol., 79: 120-134.

Abdoun, K.A., Alsofi, M.A., Samara, E.M., Alhidary, I.A., Okab,
A.B. and Al Haidary, A. 2015. Evaluation of the effects of chromium supplementation on growth and nitrogen balance of camel calves under summer conditions. Trop. Anim. Health Prod., 47(3): 619-621.

Akbarian, A., Michiels, J., Degroote, J., Majdeddin, M., Golian, A. and De Smet, S. 2016. Association between heat stress and oxidative stress in poultry; mitochondrial dysfunction and dietary interventions with phytochemicals. J. Anim. Sci. Biotechno., 7(1): 1-14.

A.O.A.C. 2005. Official Methods of Analysis, $18^{\text {th }}$ Ed. Association of Official Analytical Chemist, Benjamin Franklin Station, Washington, DC.

Bianca, W. 1962. Relative importance of dry bulb and wet bulb temperatures in causing heat stress in cattle. Nature, 195: 251-252.

Biffani, S., Bernabucci, U., Vitali, A., Lacetera, N. and Nardone, A. 2016. Effect of heat stress on nonreturn rate of Italian Holstein cows. J. Dairy Sci., 99: 5837-5843.

Bin-Jumah, M., Abd El-Hack, M.E., Abdelnour, S.A., Hendy, Y.A., Ghanem, H.A., Alsafy, S.A., Khafaga, A.F., Noreldin, A.E., Shaheen, H., Samak, D., Momenah, M.A., Allam, A.A., AlKahtane, A.A., Alkahtani, S., Abdel-Daim, M.M. and Aleya, L. 2020. Potential use of chromium to combat thermal stress in animals. Sci. Total Environ., 707: 135996.

Chauhan, S.S., Ponnampalam, E.N., Celi, P., Hopkins, D.L., Leury, B.J. and Dunshea, F.R. 2016. High dietary vitamin $\mathrm{E}$ and selenium improves feed intake and weight gain of finisher lambs and maintains redox homeostasis under hot conditions. Small Rumin. Res., 137: 17-23.

Domoslawska, A., Zdunczyk, S., Franczyk, M., Kankofer, M. and Janowski, T. 2018. Selenium and vitamin E supplementation enhances the antioxidant status of spermatozoa and improves semen quality in male dogs with lowered fertility. Andrologia, 50(6): e13023.

Duncan, D.B. 1955. Multiple range and multiple $F$ tests. Biometrics, 11: 1-42. 
Ghorbani, A., Sadri, H., Alizadeh, A.R. and Bruckmaier, R.M., 2012. Performance and metabolic responses of Holstein calves to supplemental chromium in colostrum and milk. $J$. Dairy Sci., 95: 5760-5769.

Habeeb, A.A.M. 2020. Deterioration effects of heat stress on farm animals performance in tropical and subtropical regions. World J. Biol. Pharm. Health Sci., 4(2): 7-25.

ICAR. 2013. Nutrient Requirements of Cattle and Buffalo. Indian Council of Agricultural Research, New Delhi.

Kargar, S., Mousavi, F. and Karimi-Dehkordi, S. 2018a. Effects of chromium supplementation on weight gain, feeding behaviour, health and metabolic criteria of environmentally heat-loaded Holstein dairy calves from birth to weaning. Arch. Anim. Nutr., 72: 443-457.

Kargar, S., Mousavi, F., Karimi-Dehkordi, S. and Ghaffari, M.H. 2018b. Growth performance, feeding behavior, health status, and blood metabolites of environmentally heat loaded Holstein dairy calves fed diets supplemented with chromium. J. Dairy Sci., 101: 9876-9887.

Kumar, M., Kaur, H., Deka, R.S., Mani, V., Tyagi, A.K. and Chandra, G. 2015. Dietary inorganic chromium in summerexposed buffalo calves (Bubalus bubalis): effects on biomarkers of heat stress, immune status, and endocrine variables. Biol. Trace Elem. Res., 167: 18-27.

Kumbhar, S., Khan, A.Z., Parveen, F., Nizamani, Z.A., Siyal, F.A., El-Hack, M.E.A., Gan, F., Liu, Y., Hamid, M., Nido, S.A. and Huang, K. 2018. Impacts of selenium and vitamin E supplementation on mRNA of heat shock proteins, selenoproteins and antioxidants in broilers exposed to high temperature. AMB Expr., 8(1): 112.

Lacerda, T.F. and Loureiro, B. 2015. Selecting thermotolerant animals as a strategy to improve fertility in Holstein cows. Glob. J. Anim. Sci. Res., 3: 119-127.

Lashkari, S., Habibian, M. and Jensen, S.K., 2018. A Review on the role of chromium supplementation in ruminant nutrition effects on productive performance, blood metabolites, antioxidant status and immunocompetence. Biol. Trace Elem. Res., 186: 305-321.

Mahmood, N., Hameed, A. and Hussain, T. 2020. Vitamin E and Selenium Treatment Alleviates Saline Environment-Induced Oxidative Stress through Enhanced Antioxidants and Growth Performance in Suckling Kids of Beetal Goats. Oxid. Med. Cell Longev., 2020: 1-16.

Mirzad, A.N., Tada, T., Ano, H., Kobayashi, I., Yamauchi, T. and Katamoto, H. 2018. Seasonal changes in serum oxidative stress biomarkers in dairy and beef cows in a daytime grazing system. J. Vet. Med. Sci., 18(1): 20-27.
Mousavi, F., Karimi-Dehkordi, S. and Kargar, S. 2019. Effect of chromium supplementation on growth performance, meal pattern, metabolic and antioxidant status and insulin sensitivity of summer-exposed weaned dairy calves. Animal, 13: $968-974$

Patel, M.D., Patel, J.H., Rajput, M.B. and Bariya, A.R. 2016. Adaptive physiological and biochemical responses of dairy animals to heat stress: A review. Int. J. Appl. Nat. Sci., 5(1): 107-116.

Polsky, L. and Von Keyserlingk, M.A.G. 2017. Effects of heat stress on dairy cattle welfare. J. Dairy Sci., 100: 8645-8657.

Salio, L., Gupta, I.D., Archana, V., Das, R. and Chaudhari, M.V. 2015. Association of single nucleotide polymorphism of Hsp90ab1 gene with thermotolerance and milk yield in Sahiwal cows. Afr. J. Biochem. Res., 9: 99-103.

Snedecor, G.W and Cochran, W.G. 1994. Statistical methods. $8^{\text {th }}$ Ed., Iowa State University Press, Ames, Iowa, USA-50010.

Soliman, E.B. El-Moty, K.I.A. and Kassab, A.Y. 2012. Combined effect of vitamin $\mathrm{E}$ and selenium on some productive and physiological characteristics of ewes and their lambs during suckling period. Egypt. J. sheep goat Sci., 7(2): 31-42.

Soltan, M.A., Almujalli, A.M., Mandour, M.A. and Abeer, M.E.S. 2012. Effect of dietary chromium supplementation on growth performance, rumen fermentation characteristics and some blood serum units of fattening dairy calves under heat stress. Pakistan J. Nutr., 11(9): 751-756.

Sushma, K., Reddy, Y.R., Kumari, N.N., Reddy, P.B., Raghunandan, T. and Sridhar, K. 2015. Effect of selenium supplementation on performance, cost economics, and biochemical profile of Nellore ram lambs. Vet. World, 8(9): 1150.

VanSoest, P.J., Robertson, J.B. and Lewis, B.A. 1991. Methods of dietary fibre, neutral detergent fiber, and non-starch polysaccharides in relation to animal nutrition. J. Dairy $S c i$, 74: 3583-3597.

Vinu, M.N. Gangadevi., P, Mercy, A.D., Anil, K. S. and Shyama, K. 2012. Effect of dietary supplementation of organic selenium on growth performance and nutrient utilization in cross bred calves. J. Vet. Anim. Sci., 43: 36-40.

Wang, J., Li, J., Wang, F., Xiao, J., Wang, Y., Yang, H., Li, S. and Cao, Z. 2020. Heat stress on calves and heifers. J. Anim. Sci. Biotechnol., 11(1): 18. 